\title{
Regulatory Development of Objection Legal Efforts to the Indonesia Competition Commission (KPPU) Decision After the Enactment of Law No. 11 of 2020 Concerning Job Creation
}

\author{
Zil Aidi ${ }^{1}$, Hasna Farida ${ }^{2}$ \\ \{zil.aidi93@gmail.com ${ }^{1}$, hasnaf99@gmail.com² \} \\ Universitas Diponegoro, Indonesia ${ }^{1,2}$
}

\begin{abstract}
This normative juridical research using secondary data aims to explain how and what are the reasons underlying the changes in regulations related to filing objections to the Indonesia Competition Commission (KPPU) decision after the enactment of Law No. 11 of 2020 concerning Job Creation. These changes include changing the place for filing objections from the District Court to the Commercial Court and changing the period for examining objections from the previous maximum of 30 days to a minimum of 3 months and a maximum of 12 months. These changes are to improve the quality of decisions on filing objections to KPPU's decisions. It is hoped that giving authority to the Commercial Court will provide a higher quality decision because Judges at the Commercial Court are more familiar with economic law cases. In addition, the extended time for examination of objection legal efforts will provide flexibility for the Commercial Court Judges in examining cases. In conclusion, this condition is expected to contribute to realizing a healthy business climate and attracting investment to increase Indonesia's economic growth.
\end{abstract}

Keywords: Objection Legal Efforts, KPPU Decision, Job Creation Law

\section{Introduction}

Indonesia is a country that makes the welfare of all its people the primary goal. This can be seen in the preamble to the 1945 Constitution of the Republic of Indonesia, which states that the objectives of the Government of the Republic of Indonesia are to protect the entire Indonesian and the entire homeland of Indonesia, promote public welfare, educate the nation's life, and participate in carrying out world order that is based on freedom, lasting peace and social justice.

One of Indonesia's ways to realize the welfare of its people is by applying the concept of economic democracy. The regulations regarding economic democracy are also contained in Article 33 of the 1945 Constitution of the Republic of Indonesia.

In essence, economic democracy includes three aspects. First, access to economic resources, the level of community income related to purchasing power, and workers' participation in economic activities [1]. Public access to economic resources is one of the critical essences in realizing economic democracy, which Indonesia must realize. In general, access to economic resources can be interpreted as the availability of equal opportunities for the community to participate in the production and marketing process of a product, goods, and 
services. It then became one of the considerations for the issuance of Law No. 5 of 1999 concerning the Prohibition of Monopolistic Practices and Unfair Business Competition, after this referred to as Law No. 5 of 1999.

In more detail, the reasons for the issuance of Law No. 5 of 1999 can be seen in the preamble to a quo law, namely:

a. Realizing democracy in the economic field by providing equal opportunities for every citizen to participate in the production and marketing of goods and or services in a healthy, effective and efficient business climate to promote economic growth and the operation of a fair market economy;

b. Creating a healthy and fair competition situation so that it does not lead to a concentration of economic power in certain business actors, inseparable from the Republic of Indonesia's agreements on international treaties.

In substance, Law No. 5 of 1999 regulates the prohibition of agreements, activities, and dominant positions against fair business competition [2]. Prohibited agreements include oligopoly, price-fixing, zoning, boycotts, cartels, trusts, oligopsony, vertical integration, closed agreements and agreements with foreign parties, and prohibited activities in Law No. 5 of 1999, namely monopoly, monopsony, market control, and conspiracy. Furthermore, matters that fall into a dominant position include multiple positions, share ownership, as well as mergers, consolidations, and acquisitions.

Furthermore, in addition to regulating the prohibition of activities and agreements deemed contrary to fair business competition, Law No. 5 of 1999 also regulates law enforcement and mandates the establishment of an independent institution to oversee the implementation of this law, known as the Indonesia Competition Commission/KPPU. Based on Article 1 No. 18 of Law No. 5 of 1999, KPPU is a commission established to supervise business actors in carrying out their business activities, not to exercise monopoly and/or unfair business competition. In carrying out its functions, KPPU is independent of government power and other parties' influence and is directly responsible to the President. Thus, with this regulation, KPPU has a unique position and is expected to be more effective in overcoming monopolistic practices and unfair business competition in Indonesia.

KPPU has the authority as stipulated in articles 35 and 36 of Law No. 5 of 1999. However, the duties and powers of KPPU are considered too large because there are three law enforcement functions in it, namely the police, prosecutors, and judges at the same time. KPPU conducts investigations, prosecutions and even decides on an unfair business competition case [3]. It has resulted in the emergence of authority similar to a judicial institution (quasi-judicial) in which KPPU, as an initial court, has been placed in the Indonesian legal system, then business actors who are not satisfied with the KPPU's decision can take legal efforts [4].

A series of activities carried out by the KPPU will decide whether the business actor violates the provisions in Law No. 5 of 1999 or is proven not to have violated the provisions in the law. Concerning the decision, if the business actor does not accept the decision handed down by the KPPU against it, the business actor can file a legal effort for objection.

The technical arrangements regarding the submission of objection legal efforts against the KPPU's decision can be found in the Supreme Court Regulation (PERMA) No. 3 of 2005 concerning Procedures for Submitting Objection Legal Efforts against the KPPU's Decisions which were later replaced and refined by the Supreme Court Regulation (PERMA) No. 3 of 2019 concerning Procedures for Filing Legal Efforts for Objection of the KPPU's Decision.

Regulations regarding the procedure for filing an objection again have changed with the issuance of Law No. 11 of 2020 concerning Job Creation, hereinafter referred to as Law No. 11 of 2020, along with its derivative regulations, namely Government Regulation No. 44 of 2021 
concerning the Prohibition of Monopolistic Practices and Unfair Business Competition or hereinafter referred to as Gov. Reg. No. 44 of 2021.

Based on the background and explanation above, it is interesting to answer the following problems: (1) How are the regulations regarding objection legal efforts against the Indonesia Competition Commission (KPPU) decision after the enactment of Law No. 11 of 2020 About Job Creation? (2) What are the reasons for the change in regulations related to objection legal efforts against the Indonesia Competition Commission (KPPU) decision as regulated in Law No. 11 of 2020 About Job Creation?

\section{Research Methods}

This research is normative legal research. Normative legal research is literature law research that uses secondary data related to the author's main issues [5]. Secondary data is data obtained from library materials, including official documents, books, research results in reports, diaries, and soon [6]. Meanwhile, secondary data used in this study are primary legal materials, secondary legal materials, and tertiary legal materials. The data obtained will be presented descriptively and then drawn to a conclusion using a deductive method or general to specific things.

\section{Results and Discussion}

\subsection{Regulations Regarding Legal Efforts for Objection Against the Decision of the Indonesia Competition Commission (KPPU) after the enactment of Law No. 11 of 2020 concerning Job Creation}

On November 2, 2020, the President passed Law No. 11 of 2020 concerning Job Creation. Law No. 11 of 2020 changes several provisions in Law No. 5 of 1999 concerning the Prohibition of Monopolistic Practices and Unfair Business Competition. The amendments are listed in Chapter VI concerning Ease of Doing Business, namely in Part Eleven concerning the Prohibition of Monopolistic Practices and Unfair Business Competition, precisely in Article 118.

Furthermore, on February 2, 2021, the government issued Government Regulation No. 44 of 2021 concerning the Implementation of the Prohibition of Monopolistic Practices and Unfair Business Competition, which is a derivative rule of Law No. 11 of 2020, especially regarding the Prohibition of Monopolistic Practices and Unfair Business Competition.

At least four essential changes have occurred after Law No. 11 of 2020 and its derivative regulations. First, the provisions regarding the amendment of filing an objection to the KPPU's decision previously submitted to the District Court to the Commercial Court. This provision can be found in Article 118 of Law No. 11 of 2020, which amends Article 44 paragraph (2) of Law No. 5 of 1999 .

So far, business actors can file objections to the District Court, where the business actor's legal domicile is. Based on data, in 2019, 31 KPPU decisions were stating that business actors violated Law No. 5 of 1999, of which 16 (sixteen) filed an objection process in the district court, 4 (four) appealed to the Supreme Court, and 11 cases with permanent legal force/inkracht [7]. 
As a form of follow-up to Law Number 11 of 2020 concerning Job Creation, the Supreme Court issued a Circular Letter of the Supreme Court Number 1 of 2021 concerning Transition of Examination of Objections to the Decision of the Business Competition Supervisory Commission to the Commercial Court. Through this circular, the Supreme Court determined that the district court no longer accepted any objections to the KPPU's decision as of February 2, 2021. The objection efforts were transferred to the Commercial Court.

Based on the Decree of the President of the Republic of Indonesia Number 97 of 1999, only 5 (five) Commercial Courts in Indonesia consist of the Commercial Court at the Central Jakarta District Court, the Commercial Court at the Ujung Pandang District Court (Makasar), the Commercial Court at the Medan District Court, The Commercial Court at the Surabaya District Court, and the Commercial Court at the Semarang District Court. Each Commercial Court has its jurisdiction; for example, the Commercial Court at the Central Jakarta District Court has jurisdiction covering DKI Jakarta, West Java Province, South Sumatra, Lampung, and West Kalimantan. Thus, if the domicile of the business actor is in West Java Province, an objection may be submitted to the Commercial Court at the Central Jakarta District Court.

So far, the process of transferring cases from district courts to commercial courts has been ongoing. The first attempted objection by the commercial court was the PT Conch South Kalimantan Cement (CONCH) case. On January 15, 2021, the Case Commission Council Number 03/KPPU-L/2020 decided that CONCH had violated Article 20 of Law No. 5 of 1999 concerning the Prohibition of Monopolistic Practices and Unfair Business Competition. CONCH was proven to have sold and lost in 2015 and set very low prices in 2015-2019 [8]. Regarding this decision, $\mathrm{CONCH}$ filed an objection to the Commercial Court at the Central Jakarta District Court. Regarding the objection filed by $\mathrm{CONCH}$ with case number 01/Pdt.Sus.KPPU/2021/PN.Niaga.Jkt.Pst, the Commercial Court Judge at the Central Jakarta District Court, decided to uphold the KPPU's decision Number 03/KPPU-L/2020 [8].

Secondly, it was related to the period of examination for legal efforts against the KPPU's decision. Previously in Article 45 paragraph (2), Law No. 5 of 1999 stipulated that the District Court must issue a decision within 30 days from the objection examination's commencement. After the issuance of PP. 44 of 2021 as a guideline for implementing the Prohibition of Monopolistic Practices and Unfair Business Competition, examination of objections by the Commercial Court is carried out within at least 3 months and a maximum of 12 months stipulated in Article 19 paragraph (3) of the Government Regulation.

Third, the elimination of maximum fines. The imposition of fines on business actors is one of the administrative sanctions that KPPU can impose. Previously, this was regulated in Article 47 paragraph (2) letter g, Law No. 5 of 1999, which states that administrative action can be in the form of imposition of fines of as low as IDR 1,000,000,000) one billion rupiah and a maximum of IDR 25,000,000,000. After enacting Law No. 11 of 2020 concerning Job Creation, maximum fines were abolished. Article 47 paragraph (2) letter g, Law No. 5 of 1999, is amended to state that administrative measures may include the imposition of a fine of as low as IDR $1,000,000,000$.

Although the provisions regarding the imposition of fines are abolished, based on Article 12 paragraph (1), Gov. Reg. No. 44 of 2021, administrative action in the form of fines shall be carried out with the following conditions:

a. A maximum of $50 \%$ of the profits obtained by the Business Actor in the Relevant Market, during the period of time when the violation of the Law occurs; or

b. A maximum of $10 \%$ of the total sales in the relevant market, during the period of violation of the Law. 
Determination of fines is also carried out by considering several factors such as the negative impact of violations, mitigating factors, burdensome factors, duration of violations, and business actors' ability to pay. Thus, by imposing limits on sanctions imposed by KPPU, it is hoped that it can achieve legal certainty in its implementation, and the parties can get justice.

Finally, things amended by Law No. 11 of 2020 are related to eliminating additional criminal law threats. The enactment of Law No. 11 of 2020 abolishes Article 49 of Law No. 5 of 1999, which states that by referring to the provisions of Article 10 of the Criminal Code, additional penalties as regulated in Article 48 can be imposed in the form of:

a. Revocation of business license; or

b. Prohibition on business actors who have been proven to have violated this law from serving a director or commissioner for at least two years and a maximum of 5 years; or

c. Termination of certain activities or actions that cause losses to other parties.

\subsection{Reasons for Changing Regulations Related to Objection Legal Efforts Against the Decision of the Indonesia Competition Commission (KPPU) as Regulated by Law No. 11 of 2020 concerning Job Creation}

Investment is significant for national income or Gross Domestic Product (GDP). Investment in Indonesia contributes significantly to the Gross Domestic Product, around 34\% [9]. So, if investment increases, production capacity will increase, job opportunities will open, and people's purchasing power will increase.

There is a ranking of the ease of investment or business in a country issued by the World Bank at the international level. The ranking is known as EoDB or Ease of Doing Business Index. This ranking is obtained based on the indicators set by the World Bank, which include starting a business, the ease of getting electricity access, easiness in getting credit, paying taxes, enforcing contracts, dealing with construction permits, property registration, protection of minority shareholders, trading between countries, and resolving insolvency [10]. Indonesia's position in the 2020 rankings is ranked 73rd in the world [10].

Of course, Indonesia's EoDB ranking can be said to be not good, so the government in the 2020-2024 National Medium-Term Development Plan targets to increase Indonesia's EoDB ranking from 73 to 40 in 2024. For this reason, the Government continues to strive to create a conducive climate for ease of doing business.

Meanwhile, President Joko Widodo does have a priority on improving the economy by optimally attracting investment into Indonesia. It can be seen in the first period of President Joko Widodo's administration in 2014-2019, which focused on strengthening and growing the economy with 16 Economic Policy Packages (PEK) to attract investors through relaxation of investment permits and regulations [11].

Furthermore, in the second period of President Joko Widodo's administration, the Omnibus Law on (Job Creation was passed in October 2020, aiming to stimulate the economy and attract investors to create jobs [12].

However, attracting investors is not enough just by making it easier for licensing to provide tax incentives and other matters related to other economic policies without paying attention to law enforcement aspects in Indonesia [12], mainly related to law enforcement in the field of business competition. Of course, healthy business competition can create a healthy business competition climate and create a conducive investment climate. The spirit of the passing of Law No. 5 of 1999 concerning the Prohibition of Monopolistic Practices and Unfair Business Competition, hoping that this law will provide legal certainty for business competition in Indonesia. 
In its implementation, business competition law enforcement experiences several problems, especially in relation to the District Court judge's decision on Legal Efforts to object to the KPPU's decision. Based on the data, from 2002 to 2019, there were 181 decisions in the cases processed in the District Court, about $58.5 \%$ won by KPPU, while $41.5 \%$ KPPU lost at the District Court [13]. The data shows that there are still significant disparities between the KPPU's decisions and the District Courts.

The KPPU has made efforts to understand business competition to district court judges by providing regular training. In 2019 alone, the Commission has provided Business Competition Training and Education 3 times and facilitated the visit of prospective judges to witness firsthand the implementation of court cases at KPPU [7]. The hope is that judges at district courts will better understand business competition law and can provide fair decisions for the parties. However, the training conducted by KPPU is deemed insufficient to improve the competence of district courts in handling business competition cases. In the process of examining objection efforts, there are often differences in interpretation between the KPPU and the District Court, resulting in disharmonious decisions [14].

If traced further, the condition above becomes reasonable because based on data for 2019 alone, the number of cases in district courts excluding traffic violations was 326,098 cases. The number of general court judges in 2019 is as many as 2,833 people. From this data, it can be seen that the ratio between the number of judges and the number of cases is 1:115, while the average burden per judge is 345 cases [15]. Thus, judges at district courts have a huge workload. The problems faced in business competition disputes are problems in economic law. It requires more in-depth knowledge of economic law; meanwhile, state courts are general courts that decide civil and criminal cases [16].

Starting from this problem, Law No. 11 of 2021 concerning Job Creation and its derivative regulations was born, hoping that law enforcement in the business competition will run better so that an investment ecosystem and better business competition practices will be obtained.

There is a change in filing an objection to the KPPU's decision from the District Court to the Commercial Court; it is hoped that it will improve the quality of case examinations, leading to an increase in the quality of decisions. Judges at the Commercial Court are accustomed to handling cases that intersect with business and economic law, such as bankruptcy cases, Intellectual Property Rights (IPR). Therefore, Judges at the Commercial Court are deemed to have sufficient knowledge and can understand the spirit and purpose of Law No. 5 of 1999 concerning the Prohibition of Monopolistic Practices and Unfair Business Competition [21].

In addition to that, the change in the period for examination of legal efforts against the KPPU's decision from the previous Article 45 paragraph (2), Law No. 5 of 1999, is limited to a maximum of 30 days from the start of the examination of objections by the District Court to the fastest three months and the maximum 12 months as regulated in Article 19 paragraph (3) Gov. Reg. No. 44 of 2021 is expected to provide more time for Commercial Court Judges to examine cases more carefully so that an unbiased decision can be produced and fulfills a sense of justice for the parties.

\section{Conclusion}

There are four essential changes related to filing an objection to the KPPU's decision after the promulgation of Law No. 11 of 2020 concerning Job Creation and Government Regulation No. 44 of 2021 concerning the Prohibition of Monopolistic Practices and Unfair Business 
Competition as its derivative regulations. First, concerning the location for filing an objection to the KPPU's decision which was previously at the District Court to become a Commercial Court. Second, related to the examination period for legal efforts against the KPPU's decision, which previously was a maximum of 30 days, becomes a maximum of 3 months and a maximum of 12 months. Third, the elimination of maximum fines for business actors and finally eliminating additional penalties. The reasons for this change in regulation are that the examination and decision on an objection to the KPPU's decision can achieve justice for the parties and contribute to realizing a fair business competition climate in Indonesia.

\section{Acknowledgments}

Special thanks to the Faculty of Law Universitas Diponegoro for supporting this research.

\section{References}

[1] M. D. Rahardjo, "Demokrasi Ekonomi Di Masa Depan. Pusat Studi Ekonomi dan Bisnis Islam, Fakultas Ekonomi dan Bisnis Universitas Padjadjaran", http://pusdiebi.feb.unpad.ac.id/demokrasi-ekonomi-di-masa-depan-indonesia/ (accessed Feb. 20, 2021).

[2] Wafiya, "Politik Hukum Pembentukan Undang-Undang Larangan Praktek Monopoli dan Persaingan Usaha Tidak Sehat", 2014. https://jurnal.fh.unila.ac.id/index.php/fiat/article/viewFile/323/282.

[3] B. E. Sapitri, "Kewenangan Komisi Pengawas Persaingan Usaha (KPPU) dalam penanganan perkara persaingan usaha (studi perbandingan di Indonesia dengan negara-negara common law system)". J. IUS Kaji. Huk. dan Keadilan, vol. 3, no. 1, 2015.

[4] N. L. G. E. Susilayanti and I. N. Darmadha, "Kewenangan Komisi Pengawas Persaingan Usaha (Kppu) Menyelesaikan Perkara Persaingan Usaha”, Kertha Semaya J. Ilmu Huk., pp. 1-12.

[5] S. Soekanto and S. Mamudji, "Penelitian Hukum Normatif", cetakan ke-13. Jakarta: Raja Grafindo Persada, 2011.

[6] S. Soerjono, "Pengantar Penelitian Hukum", Jakarta: Universitas Indonesia, 1986.

[7] Indonesia Competition Commission (KPPU), "Laporan Tahunan 2019: Capaian Besar Dimulai Dari Transformasi Diri”, 2019. https://kppu.go.id/wp-content/uploads/2020/06/LaporanTahunan-KPPU-2019_ok.pdf.

[8] Indonesia Competition Commission (KPPU), "Putusan KPPU atas PT. Conch South Kalimantan Cement Dikuatkan Pengadilan Niaga", https://kppu.go.id/blog/2021/03/putusankppu-atas-pt-conch-south-kalimantan-cement-dikuatkan-pengadilan-niaga/ (accessed Mar. 31, 2021)

[9] F. Rantung, "Capai 34 Persen, Kontribusi Investasi Terhadap PDB Relatif Besar", Sindonews.com, 2020. https://ekbis.sindonews.com/read/206612/33/capai-34-persenkontribusi-investasi-terhadap-pdb-relatif-besar-1603465847.

[10] World Bank, "Doing Business 2020, Economy Profile Indonesia," World Bank Group, 2020. https://www.doingbusiness.org/content/dam/doingBusiness/country/i/indonesia/IDN.pdf (accessed April 7, 2021).

[11] M. Fitriadi, M. Yudha Prawira, and Z. Aidi, "Economic Policy Package: How Policy Delivery Affects Business Competition", Proceeding International Seminar Academic Network on Competition Policy, KPPU Nusa Dua, Bali, September 6, 2017.

[12] Z. Aidi, "E-litigation as the Amenities for the Principle of Contante Justitie Manifestation of Civil Jurisdiction in Indonesia", JCH (Jurnal Cendekia Hukum), vol. 6, no. 2, pp. 206-224, 2021. 
[13] Indonesia Competition Commission (KPPU), "Rencana Strategis 2020-2024", 2020. https://kppu.go.id/wp-content/uploads/2020/07/RENSTRA-KPPU-2020-2024.FINAL-utkwebsite.pdf.

[14] N. J. R. Tobing, A. B. Prasetyo, and H. Saptono, "Tinjauan yuridis terhadap pelaksanaan eksekusi atas putusan KPPU khususnya dalam hal tender", Diponegoro Law Jourrnal., vol. 5, no. 2, pp. 1-10, 2016.

[15] Mahkamah Agung Republik Indonesia, "Laporan Tahunan 2019 Mahkamah Agung Republik Indonesia: Keberlanjutan Modernisasi Peradilan", Jakarta: Mahkamah Agung Republik Indonesia, 2019.

[16] A. Simbolon, "Kedudukan Hukum Komisi Pengawas Persaingan Usaha Melaksanakan Wewenang Penegakan Hukum Persaingan Usaha”, Mimbar Hukum-Fakultas Huk. Univ. Gadjah Mada, vol. 24, no. 3, pp. 529-541, 2012. 